\title{
PENERAPAN APLIKASI MEDIA PEMBELAJARAN PADA SMP N 1 NUSAWUNGU BERBASIS SMARTPHONE ANDROID
}

\author{
Gustin Setyaningsih $^{1}$, Muhamad Awiet Wiedanto Prasetyo ${ }^{2}$, Debby Ummul Hidayah ${ }^{3}$ \\ ${ }^{1,2,3}$ STMIK Amikom Purwokerto \\ Jl. Let. Jen. Pol. Soemarto Watumas Purwanegara Purwokerto, Banyumas 53126 \\ 1Email : gustin@amikompurwokerto.ac.id, 2Email : mawp@amikompurwokerto.ac.id, \\ ${ }^{3}$ Email : debbyummul@amikompurwokerto.ac.id
}

\begin{abstract}
ABSTRAK
Sekolah Menengah Pertama Negeri 1 Nusawaungu untuk Mata Pelajaran Biologi terdapat beberapa subpokok materi yang sulit disajikan secara langsung, salah satunya adalah materi pertumbuhan dan perkembangan, sistem gerak, sistem pernapasan, sistem peredaran darah dan sistem fotosistesis. Dari materi yang tidak dapat disajikan secara langsung, guru harus mempunyai media baru dalam menyampaikan materi biologi dan siswa dimudahkan dalam menerima penyampaian materi dari guru. Dalam kasus tersebut peneliti memiliki tujuan menerapkan media pembelajaran berbasis android mobile dengan metode Multimedia Development Life Cycle yang terdiri enam tahapan berupa Concept, Design, Material Collecting, Assembly, Testing and Distribution. Berdasarkan hasil yang diperoleh menggunakan kuesioner menyatakan dari sisi tampilan media pembelajaran mendapatkan nilai $82 \%$, dari sisi kemudahan penggunaan media pembelajaran mendapatkan 82,6\%, dari sisi pemahaman isi materi biologi mendapatkan $80 \%$ dan dari sisi efektifitas media pembelajaran membantu proses belajar mengajar mendapatkan $82,6 \%$. Sehingga dapat disimpulkan dengan media pembelajaran dapat membantu para guru dan siswa dalam proses belajar mengajar.
\end{abstract}

Kata Kunci : Biologi, Multimedia Development Life Cycle, Android Mobile

\section{ABSTRACT}

Sekolah Menengah Pertama 1 Nusawungu for Biology Subject there are several sub-subject of material that are difficult to be presented directly, one of which is material for growth and development, the motion system, respiratory system, ciculatory system and photosynthesis system. From material that cannot be presented directly, the teacher must have new media in delevering biological material and students are facilitated in receiving the material from the teacher. In that case researchers have the aim of implementing mobile android-based learning media with the Multimedia Development Life Cycle method which consist of six stages in the from concept, design, material collecting, assembly, testing and distribution. Base on the results obtained by using a questionnaire, the appearance of learning media obtained a score of $82 \%$, in terms of ease use learning media get $82,6 \%$, in terms of understanding content biological material get $80 \%$ and in terms of effectiveness learning media help the learning process get $82,6 \%$. So it can be concluede that learning media can help teachers and students in the teaching and learning process.

Keywords: Biology, Multimedia Development Life Cycle, Android Mobile.

\section{PENDAHULUAN}

Sekolah Menengah Pertama Negeri 1 Nusawungu (SMP N 1 Nusawungu) berlokasi di Jalan Sukarelawan Danasri Kecamatan Nusawungu Kabupaten Cilacap yang berjarak kurang lebih empat puluh kilometer dari pusat Ibu Kota Cilacap. SMP N 1 Nusawungu memiliki lima kelas VII, lima kelas VIII, lima kelas IX, tiga puluh sembilan tenaga pendidik (guru), dan tiga belas tenaga administrasi. Ilmu Pengetahuan Alam (IPA) merupakan ilmu yang mempelajari mengenai alam semesta beserta isinya dan peristiwa yang terjadi. Salah satu bidang pembelajaran IPA adalah Biologi.

Pada Mata Pelajaran Biologi tenaga pendidik dituntut untuk menyediakan objek bagi siswa agar dapat berinteraksi dengan objek secara langsung. Di kelas VIII untuk Mata Pelajaran Biologi banyak terdapat materi yang tidak dapat dilihat secara langsung diantaranya adalah materi pertumbuhan dan perkembangan, sistem gerak, sistem pernapasan, sistem peredaran darah dan sistem fotosistesis. Dari sub materi tersebut menjadi permasalahan siswa 
yang mengakibatkan tidak bisa mengamati atau berinteraksi secara langsung.

Kemajuan teknologi yang pesat menuntut sumber daya manusia yang berkualitas juda merupakan syarat untuk mencapai tujuan dari pendidikan. Sebagai faktor penentu keberhasilan pendidikan, maka kualitas sumber daya manusia harus ditingkatkan melalui program pendidikan yang dilaksanakan secara sistematis dan terarah berdasarkan kepentingan yang mengacu pada kemajuan ilmu pengatahuan dan teknologi.

Penggunaan teknologi komunikasi dan informasi dalam bidang pendidikan memberikan pengaruh yang sangat besar. Pada proses pembelajaran dirasakan adanya kecenderungan bergesernya pendidikan dari sistem pembelajaran yang berorientasi pada guru ke sistem yang berorientasi pada serta didik, tumbuh dan makin memasyarakatnya pendidikan terbuka dan jarak jauh, serta semakin banyaknya pilihan sumber belajar yang tersedia. Proses kegiatan belajar mengajar (KBM) di sekolah menjadi salah satu sorotan utama dalam peningkatan mutu pendidikan. Upaya peningkatan mutu pendidikan tersebut menjadi bagian terpadu dari upaya peningkatan kualitas manusia, baik asek kemampuan, kepribadian, maupun tanggung jawab. Komponen pendidikan dalam penerapannya di sekolah terdiri dari berbagai unsur, diantaranya guru, siswa dan materi ajar. Ketiga unsur tersebut akan berjalan dan saling mengisi jika metode pembelajaran, jenis media pembelajaran dan suasana yang mendukung untuk diadakannya kegiatan pembelajaran. Kegiatan belajar bertujuan untuk mencapai standar pendidikan nasional [1] .

Sampai saat ini masih banyak guru biologi menggunakan metode pembelajaran yang disebut metode konvensional, yaitu guru membacakan atau memberikan bahan yang disampaikannya sedangkan siswa mendengarkan, mencatat dengan teliti dan mencoba menyelesaikan soal sebagai mana yang dicontohkan oleh guru [2]. Kegiatan tersebut mengakibatkan para siswa cenderung pasif, sedangkan materi yang diajarkan tidak bisa diamati secara langsung. Oleh sebab itu guru hendaknya mampu memilih dan menerapkan model pembelajaran yang mampu merangsang siswa lebih aktif dalam belajar serta meningkatkan kemampuan siswa dalam memahami pelajaran. Kegiatan pembelajaran dalam pelaksanaan proses menterjemahkan dan mentransformasikan nilai-nilai yang terdapat dalam kurikulum kepada para siswa melalui interaksi belajar mengajar [3]. Proses pembelajaran biologi hendaknya para tenaga pendidik menggunakan metode yang membuat siswa banyak beraktifitas.

Dari beberapa permasalahan yang ada, diperlukan penerapan media pembelajaran yang baru dengan menggunakan metode media pembelajaran berbasis android. Penerapan media pembelajaran tersebut sudah didukung dengan para tenaga pendidik dan siswa sendiri memiliki gadget berbasis android sehingga memudahkan untuk proses belajar mengajar.

Media pembelajaran biologi diterapkan agar nantinya tenaga pendidik dimudahkan untuk menyampaikan materi dan para siswa mendapatkan nilai akhir melebihi standar uji kompetensi sekolah terutama pada mata pembelajaran biologi. Pada dasarnya android merupakan sistem operasi linux yang gratis dan memudahkan untuk berinovasi yang mendukung kegiatan keseharian kita. Framework aplication dan dalvik virtual machine yang menjadi salah satu arsitektur android untuk memungkinkan pengguna dan memeindahkan komponen yang tersedia sehingga mampu mengoptimalkan perangkat smartphone. Media pembelajaran berbasis android pastinya akan menampilkan melibatkan unsur-unsur multimedia seperti teks digital, grafik, animasi, audio, image dan video yang mampu dikendalikan oleh pengguna agar nantinya lebih interaktif [4].

Membawa teknologi baru kedalam kelas dapat menciptakan pembelajaran yang lebih inovatif. Mengembangkan media pembelajaran berbasis mobile dapat meningkatkan ketertarikan siswa terhadap proses pembelajaran. Kemudahan mengakses media tersebut juga dapat membuat siswa lebih sering membuka kembali materi yang disampaikan diluar jam pelajaran. Teknologi mobile sedang berkembang pesat ditandai dengan munculnya beberapa sistem operasi mobile seperti blackberry operating system, windows operating system dan android operating system.

Pengembangan aplikasi android didukung oleh google. Google sendiri menyediakan software untuk mengembangkan aplikasi yaitu SDK (Software Development Kit) android. SDK android ini mendukung pengembangan android yang menggunakan software eclipse maupun ADT. Google juga 
menyediakan tutorial lengkap untuk membuat aplikasi android [5].

Salah satu mobile operating system yang paling populer adalah android. Android menguasai pasar sebesar $76.3 \%$, iOS $13.2 \%$, windows Home $3.7 \%$, selebihnya Linux. Survey tersebut diambil pada kuartal ketiga tahun 2018 dari data tersebut dapat dilihat kalau android operating system mempunyai jumlah pengguna yang paling besar. Android juga merupakan sistem operasi open source sehingga relative lebih mudah untuk mengembangkan aplikasi.

Pembelajaran berbasis mobile memiliki tujuan untuk menjadi alternative layanan pembelajaran dapat dilaksanakan dimana saja dan kapan saja. Mempunyai cakupan luas karena menggunakan jaringan selular komersial dan diintegerasikan dengan berbagai sistem $e$ leraning, sistem akademik dan sistem layanan pesan instan [6].

Pembelajaran mobile dalam konteks saat ini adalah kemampuan yang diberikan kepada seseorang untuk menggunakan teknologi jaraingan mobile untuk mengakses informasi yang relevan atau menyimpan informasi baru terlepas dari lokasi fisiknya. Secara teknis dapat dikatakan pembelajaran secara pribadi yang menguhubngkan pelajat dengan komputasi awan menggunakan perangkat mobile. Pembelajaran mobile kebalikan dari pembelajaran yang terjadi dikelas tradisional dimana pelajar hanya duduk, bergerak, memperhatikan guru yang berdiri didepan kelas [7]. Untuk menyelesaikan aplikasi media pembelajaran akan menggunakan aplikasi adobe photoshop untuk pembuatan, penyuntingan dan manipulasi tampilan, termasuk koreksi warna, pemberian efek tampilan dan sabagainya dari sebuah gambar atau foto [8].

CorelDraw digunakan untuk membuat vector merubah ukuran tanpa harus mengurangi kualitas gambar dan efek blur seperti adobe photoshop [9]. Android development tools yang digunakan adalah EclipseIDE untuk memberikan integrated environment yang kuat membuat aplikasi android ADT memberikan kemmapuan kepada Eclipse untuk membuat projek baru android secara tepat, membuat aplikasi User Interface, menambahkan komponen berdasarkan Android Framework API, melakukan debugging aplikasi yang dibuat dengan menggunakan Android SDK Tools dan Bahkan melakukan distribusi aplikasi yang dibuat [10].

\section{METODOLOGI PENGUMPULAN DATA}

Pada penelitian ini menggunakan metode wawancara langsung kepada kepala sekolah, para tenaga pendidik dan para siswa untuk mengetahui permasalahan yang terjadi pada proses belajar mengajar Mata Pelajaran Biologi [11]. Selanjutnya melakukan metode observasi untuk mengamati proses belajar mengajar yang terjadi didalam kelas dan perpustakaan [12]. Untuk melakukan tahap testing dengan cara memberikan kuesioner pernyataan secara tertulis kepada responden dalam hal ini tenaga pendidik dan para siswa [13]. Menghitung hasil kuesioner menggunakan Skala Likert untuk mengukur sikap, pendapat dan persepsi seseorang tentang variable atau indikator didalam kuesioner penyataan [14].

\section{METODE PENGEMBANGAN SISTEM}

Metode pengembangan sistem menggunakan Multimedia Development Life Cycle yang terdiri dari enam tahap yaitu Concept, Design, Material Collecting, Assembly, Testing dan Distribution [15].

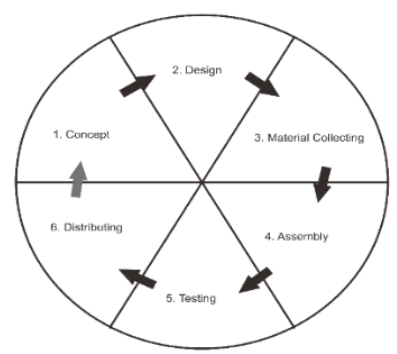

Gambar 1. Metode Pengembangan Sistem

\section{HASIL DAN PEMBAHASAN}

\section{CONCEPT}

Sebelum menerapkan media pembelajaran biologi, peneliti melakukan pengkonsepan meliputi sub materi yang berjumlah delapan bab yang berdasarkan dari buku panduan Belajar IPA Biologi yang bertujuan menghasilkan aplikasi media pembelajaran yang mudah digunakan oleh para tenaga pendidik dan siswa sebagai user dengan menggabungkan beberapa elemen-elemen multimedia.

Media pembelajaran diawali dengan tampilan icon aplikasi kemudian menu utama berisi button materi, button soal, button bantuan, button tentang dan button keluar. Selanjutnya untuk setiap scene memiliki button selanjutnya 
dan button keluar. Untuk pengemasan aplikasi media pembelajaran berupa file berekstensi apk.

\section{DESIGN}

Tahap perancangan menggunakan storyboard untuk menggambarkan alur perancangan desan tampilan dan menggambarkan deskripsi dari setiap layout dengan mencantumkan semua objek multimedia dan penentuan tautan dari layout ke layout yang lain dengan menggunakan perancangan struktur navigasi hierarki. Aplikasi media pembelajaran biologi dirancang dalam bentuk menu-menu pilihan yang akan mengakses ke halaman yang user inginkan. Struktur navigasi berfungsi untuk menggambarkan dengan jelas hubungan antar elemen yang akan digunakan dalam aplikasi.

Dengan penggambaran struktur navigasi, pembuatan aplikasi media pembelajaran biologi ini dapat sistematis dan mudah digunakan. Sebagai perancangan struktur navigasi dapat dilihat pada Gambar 2. Struktur Navigasi Aplikasi:

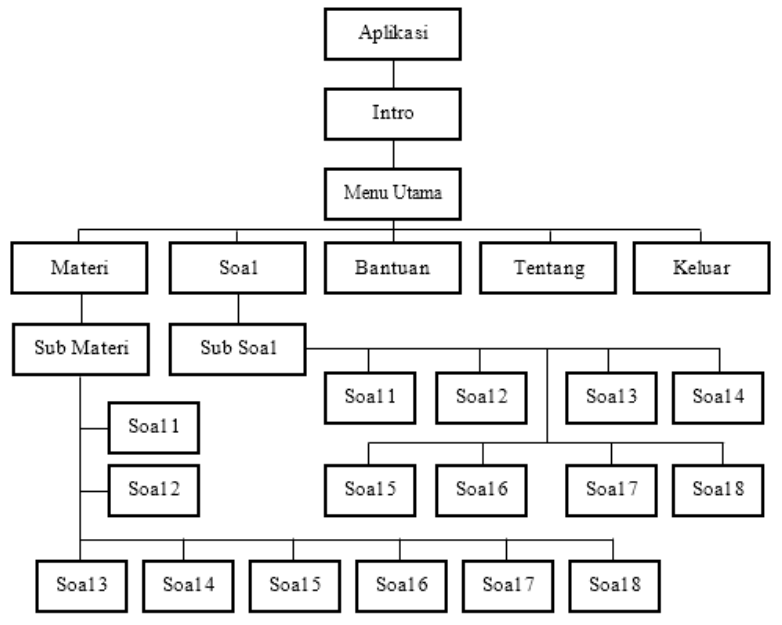

Gambar 2. Struktur Navigasi Aplikasi

\section{MATERICAL COLLECTING}

Bahan yang akan dikumpulkan adalah gambar, teks dan suara. Sebagian besar gambar dan teks pendukung dibuat kemudian diedit menggunakan perangkat lunak CorelDraw X7 dan Adobe Photoshop CS6 sedangkan proses pengeditan suara diedit dengan perangkat lunak Adobe Audition. Tampilan intro aplikasi dapat dilihat pada Gambar 3. Background Intro, untuk Button Navigasi salah satunya seperti Gambar 4. Tombol Navigasi.

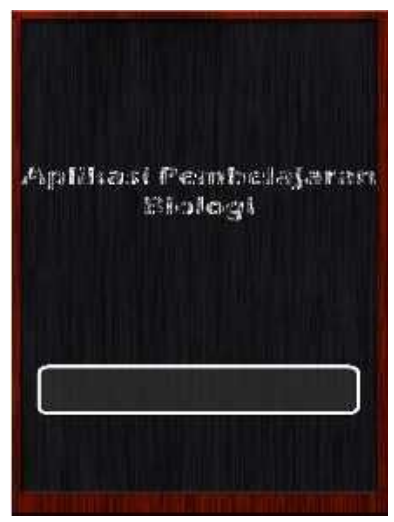

Gambar 3. Background Intro

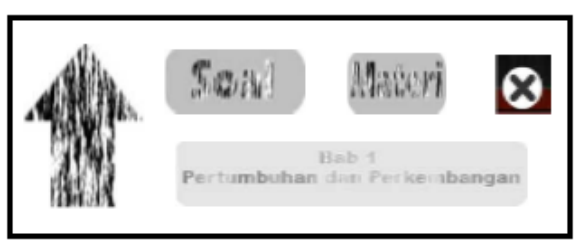

Gambar 4. Button Navigasi

\section{ASSEMBLY}

Semua bahan pendukung yang telah dikumpulkan dibuat dan desain ditranslasikan ke dalam software. Bahan pendukung yang digunakan dalam proses ini yaitu gambar, teks dan suara. Tahapan-tahapan pembuatan aplikasi media pembelajaran sebagai berikut:

\section{MENU AWAL}

Berdasarkan pada Gambar 5. Tampilan Intro, ketika user menjalankan aplikasi akan menampilkan loading hingga selesai dan muncul button menu belajar untuk melanjutkan menu selanjutnya.

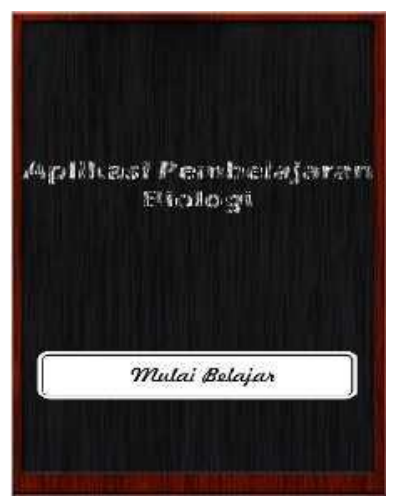

Gambar 5. Tampilan Intro

Sedangkan pada Gambar 6. Menu Materi, merupakan tampilan yang berisi sub materi dari materi bab satu sampai dengan bab delapan. 


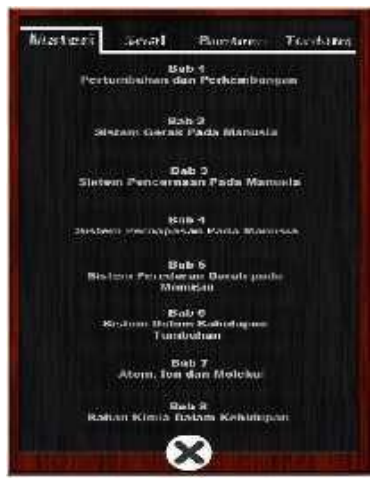

Gambar 6. Menu Materi

Selanjutnya pada Gambar 7. Menu Soal, merupakan tampilan yang berisi latihan soal yang akan digunakan sebagai uji kompetensi dari bab satu sampai dengan bab delapan.

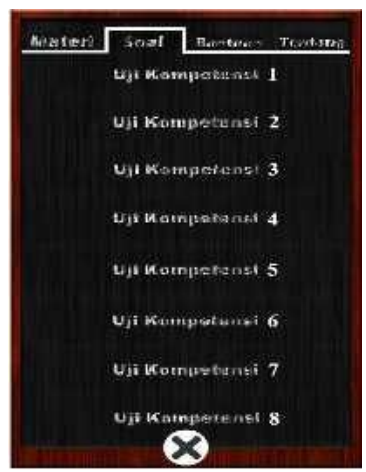

Gambar 7. Menu Soal

\section{MENU BANTUAN DAN MENU TENTANG}

Berdasarkan pada Gambar 8. Menu Bantuan, merupakan tampilan yang berisi latihan soal yang akan digunakan sebagai bantuan untuk penggunaan aplikasi.

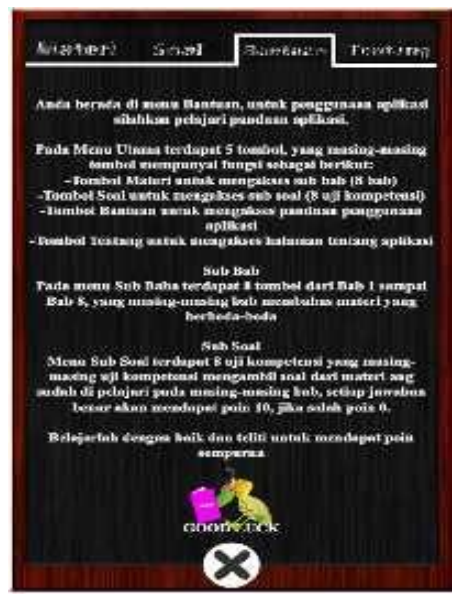

Gambar 8. Menu Bantuan
Sedangkan pada Gambar 9. Menu Tentang, merupakan tampilan yang berisi tentang software yang digunakan pembuatan aplikasi media pembelajaran.

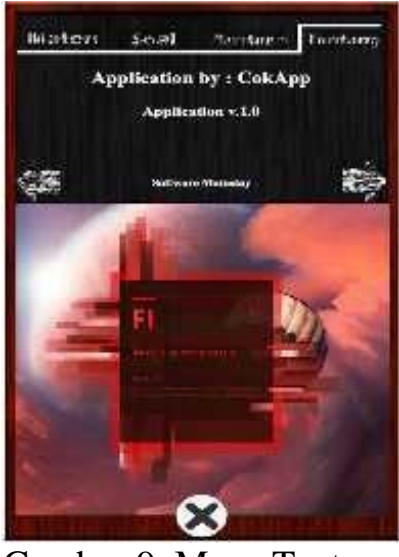

Gambar 9. Menu Tentang

\section{MENU SETIAP MATERI}

Berdasarkan pada Gambar 10. Materi Bab 1, merupakan tampilan yang berisi dari bab satu menjelaskan materi pertumbuhan dan perkembangan. Sub pokok bahasan yang akan dibahas meliputi perkembangan kedewasaan atau kemampuan seseorang, perubahan ukuran tubuh, pertumbuhan masa fetus, masa balita, masa anak-anak, masa remaja, masa dewasa dan masa tua, perkembangbiakan dengan cara melahirkan atau pembuahan, tahapan perkembangan didalam rahim, masa pubertas, perubahan fisik, cara menjaga kesehatan alat reproduksi, cara menjaga kesehatan tubuh.

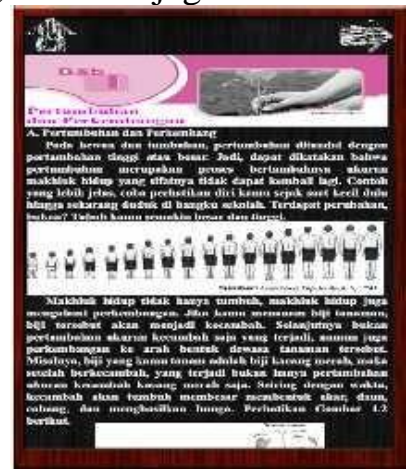

Gambar 10. Materi Bab 1

Gambar 11. Materi Bab 2, menjelaskan materi sistem gerak pada manusia. Sub pokok bahasan yang akan dibahas meliputi fungsi tulang atau rangka didalamnya bagian tengkorak, bagian badan, bagian angora gerak, anggota gerak atas, anggota gerak bawah. jenisjenis tulang didalamnya tulang rawan, tulang keras, bentuk tulang, tulang pipa, tulang pipih, 
tulang pendek. Kelainan pada tulang didalamnya scoliosis, kifosis, polio dan rakhitis. Persendian didalamnya macam-macam sendi, sendi mati, sendi gerak, sendi engsel, sendi pelana, sendi geser, sendi putar, sendi peluru. Otot didalamnya jenis-jenis otot, otot polos, otot jantung, otot lurik. Gerak dan kerja otot didalamnya gerak sinergis, gerak antagonis, kelainan pada otot didalamnya tetanus, atrofi, kram dan terkilir.

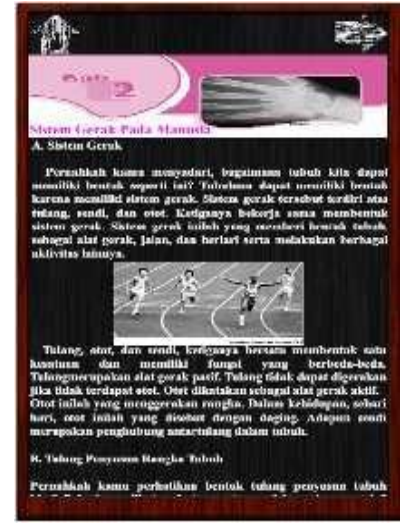

Gambar 11. Materi Bab 2

Gambar 12. Materi Bab 3, menjelaskan materi sistem pencernaan pada manusia. Sub pokok bahasan yang akan dibahasan meliputi pencernaan mekanik, pencernaan kimiawai, penyerapan dan penyingkirian. Organ sistem pencernaan didalamnya ada saluran pencernaan dan organ pencernaan tambahan. Bagian-bagian sistem pencernaan. Proses pencernaan makanan pada organ pencernaan tubuh. Gangguan pada system pencernaan didalamnya ada gastristis, hepatitis, diare, konstipasi, apendisitis, hemeroid, wasir, ambeyen, maag, keracunan, tukak lambung dan malnustrisi.

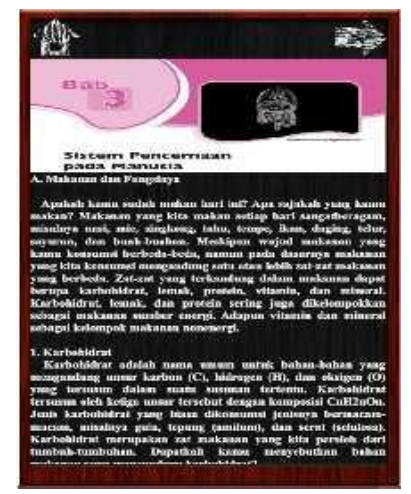

Gambar 12. Materi Bab 3

Gambar 13. Materi Bab 4, menjelaskan materi sistem pernafasan pada manusia. Sub pokok bahasan yang akan dibahas meliputi alat dan bagian sistem penafasan, proses sistem pernafasan, jenis pernafasan dan penyakit sistem pernafasan.

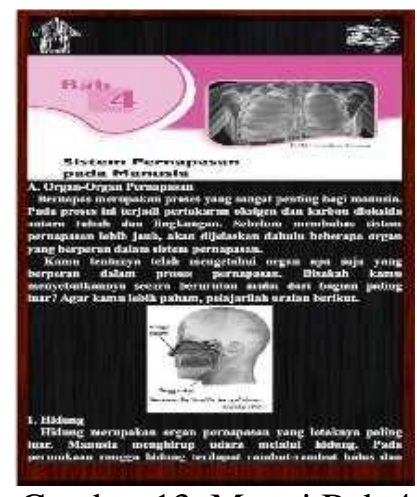

Gambar 13. Materi Bab 4

Gambar 14. Materi Bab 5, menjelaskan tentang materi sistem peredaran darah pada manusia. Sub pokok bahasan yang akan dibahas meliputi komponen sistem peredaran darah, fungsi darah, darah, pembuluh darah, jantung, mekanisme kerja jantung, jenis-jenis peredaran darah, penggolongan darah dan gangguan sistem peredaran darah.

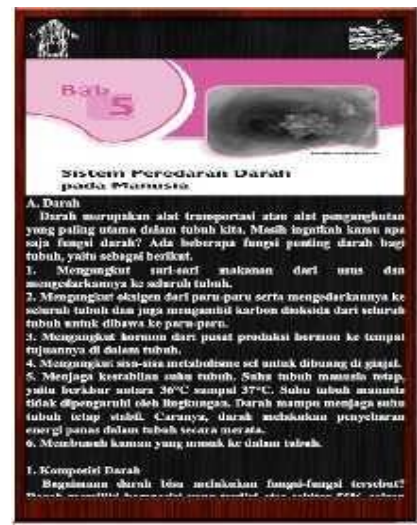

Gambar 14. Materi Bab 5

Gambar 15. Materi Bab 6, menjelaskan tentang materi sistem dalam kehidupan tumbuhan. Sub pokok bahasan yang akan dibahas meliputi jaringan meristem, jaringan epidermis, jaringan parenkim, jaringan pengankut dan jaringan penguat. Organ pada tumbuhan, fotosistesis, gerak pada tumbuhan, hama dan penyakit pada tumbuhan. 


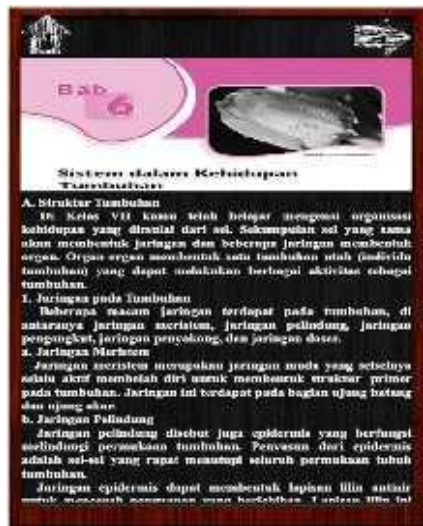

Gambar 15. Materi Bab 6

Gambar 16. Materi Bab 7, menjelaskan tentang materi atom, ion dan molekul. Sub pokok bahasan yang akan dibahas meliputi proton, neutron dan elektron. Molekul unsur dwiatom, triatom dan treaatom.

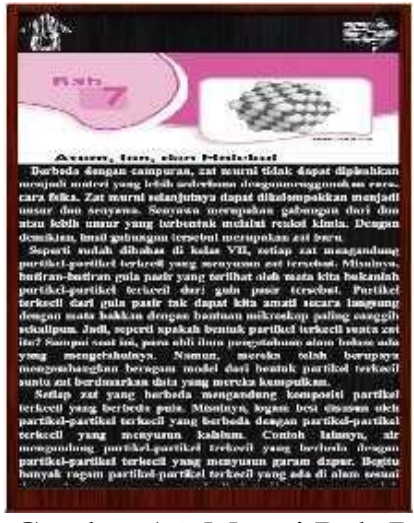

Gambar 16. Materi Bab 7

Gambar 17. Materi Bab 8, menjelaskan materi bahan kimia dalam kehidupan. Sub pokok bahasan yang akan dibahasa meliputi sifat bahan kimia, berbahan kertas, kaleng atau botol, botol bermulut sempit dan tertutup rapat. Bahan kimia pembersih seperti sabun, deterjen, pasta gigi, sampo. Bahan pemutih, bahan pewangi seperti fanil alkohol, sitrat, ambergris, gray amber, casturium, C/Vet dari pewangi padat, car dan aerosol cair. Bahan pembasmi serangga, pupuk.

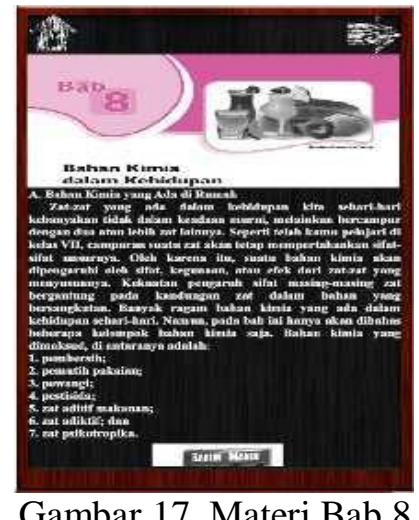

\section{UJI KOMPETENSI}

Berdasarkan pada Gambar 18. Uji Kompetensi Satu, merupakan tampilan berisi materi perkembangan kedewasaan atau kemampuan seseorang, perubahan ukuran tubuh, pertumbuhan masa fetus, masa balita, masa anak-anak, masa remaja, masa dewasa dan masa tua, perkembangbiakan dengan cara melahirkan atau pembuahan, tahapan perkembangan didalam rahim, masa pubertas, perubahan fisik, cara menjaga kesehatan alat reproduksi, cara menjaga kesehatan tubuh.

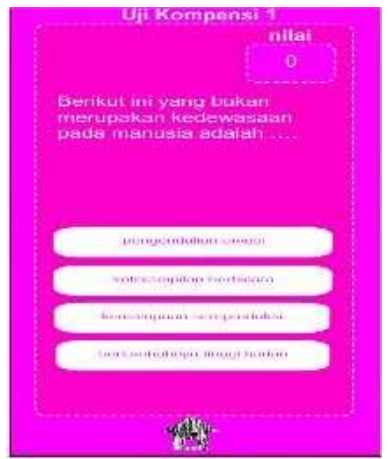

Gambar 18. Uji Kompetensi Satu

Gambar 19. Uji Kompetensi Dua, merupakan tampilan berisi materi fungsi tulang atau rangka didalamnya bagian tengkorak, bagian badan, bagian angora gerak, anggota gerak atas, anggota gerak bawah. jenis-jenis tulang didalamnya tulang rawan, tulang keras, bentuk tulang, tulang pipa, tulang pipih, tulang pendek. Kelainan pada tulang didalamnya scoliosis, kifosis, polio dan rakhitis. Persendian didalamnya macam-macam sendi, sendi mati, sendi gerak, sendi engsel, sendi pelana, sendi geser, sendi putar, sendi peluru. Otot didalamnya jenis-jenis otot, otot polos, otot jantung, otot lurik. Gerak dan kerja otot didalamnya gerak sinergis, gerak antagonis, 
kelainan pada otot didalamnya tetanus, atrofi, kram dan terkilir.

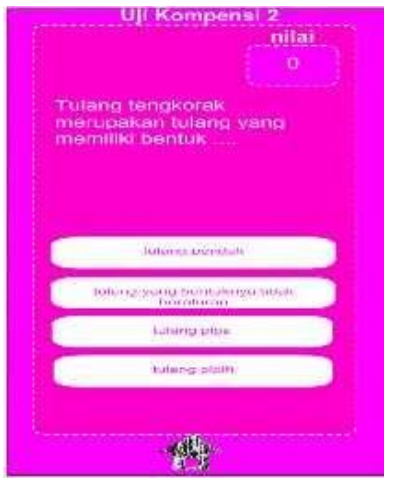

Gambar 19. Uji Kompetensi Dua

Gambar 20. Uji Kompetensi Tiga, merupakan tampilan berisi materi pencernaan mekanik, pencernaan kimiawai, penyerapan dan penyingkirian. Organ sistem pencernaan didalamnya ada saluran pencernaan dan organ pencernaan tambahan. Bagian-bagian sistem pencernaan. Proses pencernaan makanan pada organ pencernaan tubuh. Gangguan pada system pencernaan didalamnya ada gastristis, hepatitis, diare, konstipasi, apendisitis, hemeroid, wasir, ambeyen, maag, keracunan, tukak lambung dan malnustrisi.

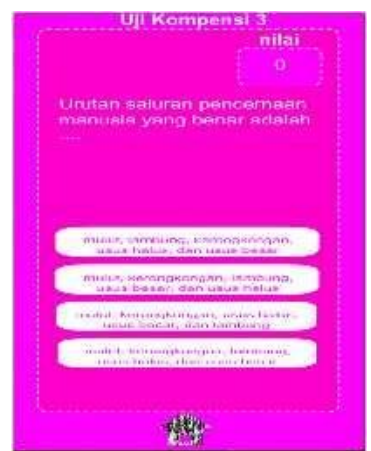

Gambar 20. Uji Kompetensi Tiga

Gambar 21. Uji Kompetensi Empat, merupakan tampilan berisi materi alat dan bagian sistem penafasan, proses sistem pernafasan, jenis pernafasan dan penyakit sistem pernafasan.

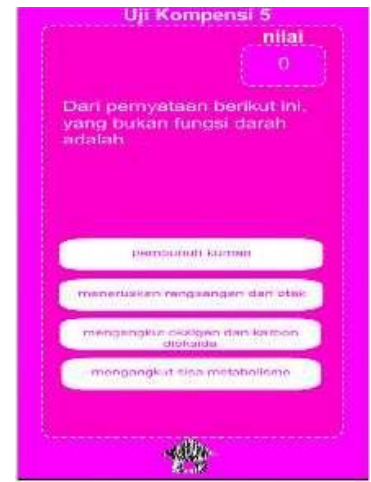

Gambar 21. Uji Kompetensi Lima

Gambar 22. Uji Kompetensi Lima, merupakan tampilan berisi materi komponen sistem peredaran darah, fungsi darah, darah, pembuluh darah, jantung, mekanisme kerja jantung, jenis-jenis peredaran darah, penggolongan darah dan gangguan sistem peredaran darah.

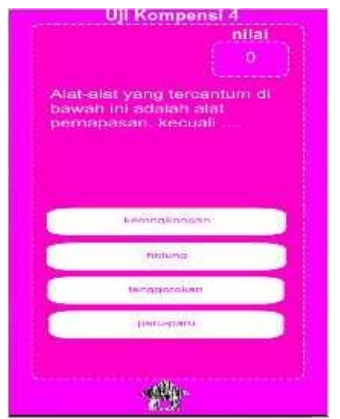

Gambar 22. Uji Kompetensi Empat

Gambar 23. Uji Kompetensi Enam, merupakan tampilan berisi materi jaringan meristem, jaringan epidermis, jaringan parenkim, jaringan pengankut dan jaringan penguat. Organ pada tumbuhan, fotosistesis, gerak pada tumbuhan, hama dan penyakit pada tumbuhan.

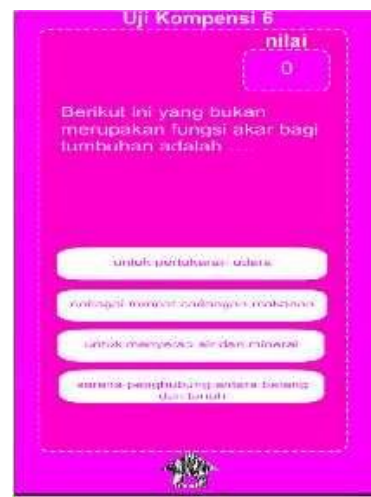

Gambar 23. Uji Kompetensi Enam 
Gambar 24. Uji Kompetensi Tujuh, merupakan tampilan berisi materi proton, neutron dan elektron. Molekul unsur dwiatom, triatom dan treaatom.

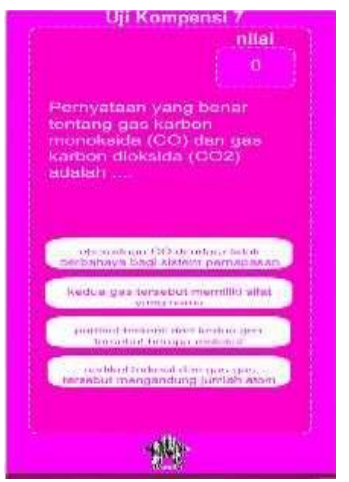

Gambar 24. Uji Kompetensi Tujuh

Gambar 25. Uji Kompetensi Delapan, merupakan tampilan berisi materi sifat bahan kimia, berbahan kertas, kaleng atau botol, botol bermulut sempit dan tertutup rapat. Bahan kimia pembersih seperti sabun, deterjen, pasta gigi, sampo. Bahan pemutih, bahan pewangi seperti fanil alcohol, sitrat, ambergris, gray amber, casturium, C/Vet dari pewangi padat, car dan aerosol cair. Bahan pembasmi serangga, pupuk.

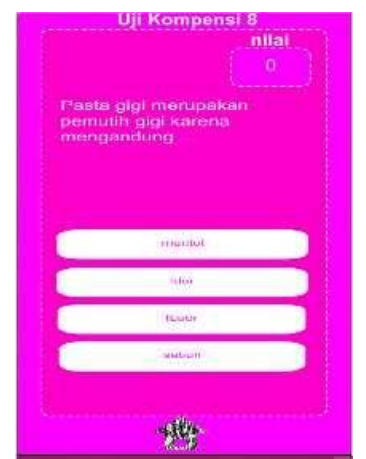

Gambar 25. Uji Kompetensi Delapan

\section{TESTING}

Tahap pengujian untuk memastikan komponen-komponen dari sistem yang sudah berfungsi dengan baik atau tidak dan mengetahui kesalahan yang mungkin terjadi. Tahap pengujian aplikasi menggunakan alpha test dengan melakukan pengujian aplikasi yang sudah dilakukan tahap assembly dan mendapatkan hasil sesuai yang diharapkan berjalan dengan baik meskipun sudah dilakukan secara berlang-ulang. Sedangkan tahap beta test dilakukan uji kelayakan aplikasi kepada tenaga pendidik dan siswa sebagai responden.

\begin{tabular}{|c|l|l|l|l|l|l|}
\hline \multirow{2}{*}{ No } & \multirow{2}{*}{ Aspek Penilaian } & \multicolumn{5}{|c|}{ Penilaian } \\
\cline { 3 - 7 } & & SS & S & N & TS & STS \\
\hline 1 & $\begin{array}{l}\text { Tampilan Aplikasi } \\
\text { Biologi Menarik }\end{array}$ & 3 & 27 & 0 & 0 & 0 \\
\hline 2 & $\begin{array}{l}\text { Aplikasi Biologi } \\
\text { Mudah Digunakan } \\
\text { Dibandingkan Dengan } \\
\text { Buku Panduan Belajar } \\
\text { Siswa }\end{array}$ & 4 & 26 & 0 & 0 & 0 \\
\hline 3 & $\begin{array}{l}\text { Aplikasi Biologi } \\
\text { Membuat Mudah } \\
\text { Dalam Memahami } \\
\text { Pelajaran Biologi }\end{array}$ & 30 & 0 & 0 & 0 & 0 \\
\hline 4 & $\begin{array}{l}\text { Apakah Aplikasi } \\
\text { Biologi Lebih Efektif } \\
\text { Dalam Kegiatan } \\
\text { Belajar Dibandingkan } \\
\text { Dengan Buku Panduan } \\
\text { Belajar Siswa }\end{array}$ & 4 & 26 & 0 & 0 & 0 \\
& & & & & & \\
& & & & & \\
\end{tabular}

Kemudian menghitung jumlah skor dan total skor dengan rumus sebagai berikut :

Jumlah Skor $=\mathrm{T} \times \mathrm{Pn}$

$\mathrm{T}=$ total responden yang memilih

$\mathrm{Pn}=$ pilihan angka skor likert

Jumlah skor pernyataan nomor 1:

1) Sangat Setuju (5) $=3 \times 5=15$

2) Setuju (4) $=27 \times 4=108$

3) $\operatorname{Netral}(3)=0 \times 3=0$

4) Tidak Setuju (2) $=0 \times 2=0$

5) Sangat Tidak Setuju (1) $=0 \times 1=0$

Diperoleh total skor $=123$

Selanjutnya menghitung dengan rumus index sebagai berikut :

Rumus Index $\%=$ Total Skor $/ Y$ x 100

$$
\begin{aligned}
& =123 / 150 \quad \mathrm{x} 100 \\
& =82 \%
\end{aligned}
$$

Jumlah skor pernyataan nomor 2:

1) Sangat Setuju (5) $=4 \times 5=20$

2) Setuju (4) $=26 \times 4=104$

3) $\operatorname{Netral}(3)=0 \times 3=0$

4) Tidak Setuju (2) $=0 \times 2=0$

5) Sangat Tidak Setuju (1) $=0 \times 1=0$

Diperoleh total skor $=124$

Rumus Index \% = Total Skor $/ Y$ x 100

$$
\begin{aligned}
& =124 / 150 \times 100 \\
& =82,6 \%
\end{aligned}
$$

Jumlah skor pernyataan nomor 3 :

1) Sangat Setuju (5) $=0 \times 5=0$

2) Setuju (4) $=30 \times 4=120$

3) $\operatorname{Netral}(3)=0 \times 3=0$

4) Tidak Setuju (2) $=0 \times 2=0$

5) Sangat Tidak Setuju (1) $=0 \times 1=0$ 
Diperoleh total skor $=120$

Rumus Index \% = Total Skor/Y x 100

$$
\begin{aligned}
& =120 / 150 \times 100 \\
& =80 \%
\end{aligned}
$$

Jumlah skor pernyataan nomor 4 :

1) Sangat Setuju (5) $=4 \times 5=20$

2) Setuju (4) $=26 \times 4=104$

3) $\operatorname{Netral}(3)=0 \times 3=0$

4) Tidak Setuju (2) $=0 \times 2=0$

5) Sangat Tidak Setuju (1) $=0 \times 1=0$

Diperoleh total skor $=124$

Rumus Index \% = Total Skor/Y x 100

$$
\begin{aligned}
& =124 / 150 \times 100 \\
& =82,6 \%
\end{aligned}
$$

Setelah penghitungan dengan rumus index selesai, diperlukan kriteria interpretasi skor berdasarkan interval atau jarak. Rumus interval dalam bentuk persentase sebagai berikut:

$\mathrm{I}=100 /$ Jumlah nilai likert

Maka $I=100 / 5=20$ sehingga dihasilkan interval sebesar 20. Interval dari terendah $0 \%$ hingga tertinggi $100 \%$.

Berikut interpretasi skor berdasarkan interval :

1) Angka 0\%-19,99\% = Sangat Tidak Setuju

2) Angka 20\% - 39,99\% = Tidak Setuju

3) Angka 40\% - 59,99\% = Netral

4) Angka $60 \%-79,99 \%=$ Setuju

5) Angka $80 \%-100 \%=$ Sangat Setuju

Dari hasil beta test untuk tampilan aplikasi biologi mendapatkan nilai $82 \%$, untuk kemudahan penggunaan aplikasi mendapatkan nilai $82,6 \%$, untuk pemahaman materi pada aplikasi mendapatkan nilai $80 \%$, sedangkan tingkat efektifitas sebagai media pembelajaran baru mendapatkan nilai $82,6 \%$. Secara keseluruhan $(82 \%+82,6 \%+80 \%+82,6 \%) / 4=$ $81,8 \%$ dan tergolong dalam kategori sangat baik.

\section{DISTRIBUTION}

Aplikasi media pembelajaran biologi dengan cara menyimpan aplikasi pada smartphone android dengan ekstensi .apk. pendistribusian aplikasi ini dibagikan kepasa tenaga pendidik dan siswa SMP N 1 Nusawungu Cilacap melalui bluetooth.

\section{SIMPULAN DAN SARAN}

Berdasarkan hasil analisis maka dapat disimpulkan, media pembelajaran digunakan tenaga pendidik untuk menyampaikan materi secara mudah dan para siswa mendapatkan nilai akhir melebihi standar uji kompetensi sekolah terutama pada mata pembelajaran biologi, sedangkan tahap testing aplikasi setelah diakumulasi secara keseluruhan mendapatkan nilai $81,8 \%$ masuk dalam kategori sangat baik.

\section{UCAPAN TERIMA KASIH}

Peneliti mengucapkan terima kasih kepada semua pihak yang telah mendukung dalam menyelesaikan penelitian ini dalam bentuk waktu, motivasi, dan juga pengetahuan.

\section{REFERENSI}

[1] S. Sandi Sanjaya, "Penerapan Media Pembelajaran Lectora Inspire Untuk Meningkatkan Minat dan Prestasi Belajar Perhitungan Konstruksi Mesin Siswa Kelas XI Mesin di SMK Piri Sleman," $J$. Taman Vokasi, vol. 5, no. 1, pp. 56-61, 2017.

[2] R. N. Hidayati, "Aplikasi Pembelajaran Problem Posing Dalam Meningkatkan Hasil Belajar Biologi Pokok Bahasan Ekosistem Pada Siswa Kelas VIIE SMP Muhammadiyah 5 Surakarta Tahun Ajaraan 2007/2008," Universitas Muhammadiyah Surakarta, 2008.

[3] N. A. P. Kusuma, "Rancang Bangun Media Pembelajaran Biologi untuk Sekolah Menengah Pertama Kelas VIII Berbasis Multimedia," Universitas PGRI Yogyakarta, 2016.

[4] F. Sukmawati, "Pengembangan Aplikasi Pembelajaran Biologi SMP Berbasis Android Untuk Bekal Menghadapi UAN Di SMP Islam Bakti 1 Surakarta," Prosiding Pascasarjana Program Studi Teknologi Pendidikan Universitas Sebelas Maret, no. November, pp. 102114, 2015.

[5] S. Yuntoto, "Pengembangan Aplikasi Android Sebagai Media Pembelajaran Kompetensi Pengoperasian Sistem Pengendali Elektronik pada Siswa Kelas XI SMK N 2 Pengasih," Universitas Negri Yogyakarta, 2015.

[6] D. Darmawan, Teknologi Pembelajaran. Bandung: Remaja Rosdakarya, 2012.

[7] G. Woodill, The Mobile Learning Edge: 
Tools and Technologies foe Development Your Teams. McGraw Hill Professiol, 2010.

[8] Madcoms, Mahir Dalam 7 Hari Adobe Photoshop CS. Yogyakarta: Penerbit ANDI, 2005.

[9] H. Hendrataman, The MAgic of CorelDraw. Bandung: Penerbit Informatika, 2009.

[10] I. Ripai, "Rancang Bangun Aplikasi Android Kitab Bulughul Maram Menggunakan Eclipse," J. ICT Learn., vol. 2, no. 2, pp. 19-24, 2016.

[11] Sudaryono, Pengantar Sistem Informasi. Yogyakarta: Graha Ilmu, 2010.

[12] M. Nazir, Metode Penelitian. Bogor: Ghalia Indonesia, 2010.

[13] Sudaryono, Metodologi Penelitian. Jakarta: PT Raja Grafindo Persada, 2017.

[14] Sugiyono, Pengantar Sistem Informasi. Yogyakarta: Graha Ilmu, 2012.

[15] I. Binanto, Multimedia Digital Dasar Teori dan Pengembangannya. Yogyakarta: Penerbit ANDI, 2010. 